\title{
Internal and International Vertical Specialization of Brazilian states- An Input-Output analysis
}

\author{
Joaquim GUILHOTO ${ }^{1}$ \\ Jean-Marc SIROËN ${ }^{2,3}$ \\ Aycil YUCER ${ }^{2,3,4}$
}

\begin{abstract}
:
WTO, OECD with many others, suggest the trade in value-added would be a "better" measure to understand the impact of trade on employment, growth, production etc. when import content in exports is important. We use in this work an Input-Output table for 2008, to calculate the value-added exported by Brazilian states. We distinguish the valueadded exported directly by the state itself or indirectly via other states. Then, we define the extent of vertical specialization among Brazilian states by using value-added indirectly exported. We calculate equally the import content in states' exports. If the share of import content in Brazilian exports is low, we show evidence that inter-state trade is quite high across some Brazilian states. Inter-state vertical specialization then operates at upstream stages of the value chain before the good be exported to foreign countries.
\end{abstract}

Keywords: Vertical Specialization, Global supply-chain, Input-Output Analysis, Brazil, intra-national trade

JEL classification: F02, F15, R12, R15

1- Universidade de São Paulo, FEA, NEREUS

2- Université Paris-Dauphine, LEDa, 75775 Paris Cedex 16

3-IRD, UMR225, DIAL, 75010 Paris

4-Department of Economics, Dokuz Eylul University, Izmir 35160 Turkey 


\section{Introduction}

The goods exported by a country are rarely produced entirely within the country, which implies that the export values are made up partly of imported value-added. Indeed, the contribution of exports to the exporting country's growth, employment and balance of trade depends solely on its own value-added or, in other words, on the domestic value-added. The 1998 WTO Annual Report estimated that a mere $37 \%$ of the production value of a typical American car is generated in the US. More recent case studies are available for the iPod, iPhone (Dedrick, Kraemer, \& Linden, 2010), the Nokia N95 (Ali-Yrkkö, Rouvinen, Seppälä, \& Ylä-Anttila, 2011), and even ... Barbie dolls (Maurer \& Degain, 2010), (World Economic Forum, 2012).

The collapse of international trade from mid-2008 to mid-2009 was striking with a $38 \%$ fell in world exports and a massive $53 \%$ for China in just nine months ${ }^{1}$. Many explanations have been advanced such as a trade transaction "credit crunch". Nevertheless, the "vertical specialization" process appears to play an important role in this surprisingly deeper and sudden recession (Liu, 2011) (Escaith, Lindenberg, \& Miroudot, 2010). The "vertical specialization”, defined more precisely by (Hummels, Rapoport, \& Yi, 1998), “... occurs when a country uses imported intermediate parts to produce goods it later exports". It notably implies that the value-added of a component may be recorded several times in the trade statistics, i.e. each time it crosses the border for use in a new stage of the production process (Koopman, Wang, \& Wei , 2012). However, the trade statistics continue to be presented in terms of gross value and theory, statistics, analyses and textbooks view still often the entire gross value of exports as if it were made up solely of domestic value-added, disregarding the import content (or foreign value-added) of exports.

Then, the three following conditions need to be held: (1) A good must be produced in multiple sequential stages; (2) Two or more countries have to specialize in producing some, but not all stages; (3) At least one stage must cross an international border more than once. More fragmented the "international supply chain", the more countries will be specialized in "tasks" (design, assembly, transport, distribution, etc.) instead of goods (cars, computers, etc.) and more they become interconnected with production chains. For example, China is not specialized in exports of laptops, but after importing the technology and the components, is mainly specialized in the assembly of the final good, which is situated at the final stage of the industrial process (Koopman, Wang, \& Shang-Jin, 2008). Recent studies confirm the trend to the deepening of vertical specialization. For example, the ratio of value added to gross trade would have fallen by ten to fifteen percentage points, with two-thirds of this decline in the last two decades (Johnson \& Noguera , 2012) what is confirmed by other studies (OECD, 2011).

Trade in tasks (or vertical specialization) occurs when the additional cost of geographic fragmentation in production process is less than the cost advantage gained through the spatial differences of factor endowments, production technology and/or trade costs. Hence, the

\footnotetext{
${ }^{1}$ WTO statistics.
} 
dynamics pushing for the vertical specialization in world markets can also be at work in domestic markets.

The relatively good trade integration of domestic markets should facilitate the product value chain inside the country with low costs in components trade. Furthermore, new business management practices have reduced the cost of coordination though within a country. Nevertheless, under the classical assumptions of traditional trade theories, with factors of production being perfectly mobile in national markets, relative endowments are uniform in space. If that were true, all the regions in a country would have similar comparative advantages and the company would gain nothing, but face only extra costs from splitting up the production chain across the country.

However, in reality, neither factor nor good markets are really "perfectly" integrated. Factors of production are not completely mobile, even within one country. A country's regions may differ from in terms of their specializations and production costs. So there could be a gain in producing tasks in different regions of a country. This is especially true for developing and emerging markets, such as Latin American countries, India and China, where regional differences are considerable. On the other hand, transaction costs and the trade integration of goods markets can also differ across the regions of a country. Wolf (2000) calls this the spatial non-linearities ${ }^{2}$ of transaction costs and states that, under these non-linearities, the production of tasks in a country will be spatially concentrated, instead of being spread out geographically, and trade in intermediate goods will take place among close entities.

Brazil is a specific case. Brazil's rate of openness is low compared to other large emerging countries such as China or India. However, the domestic value-added content of Brazilian exports is probably higher (or the import content lower) since Brazilian specialization is mainly in tasks located at the early stages of the supply chain, such as raw materials, e.g. compared to China.

Brazil's poor performance in terms of openness does not obviously imply a low level of specialization along the domestic supply chain. Considering the high heterogeneity of Brazilian regions notably in terms of climate, location and factor endowment, there is room for large specialization differences within Brazil and hence for vertical specialization. Yet although states' trade statistics are available, they are given in gross value and we have no information on the shares of own domestic value-added and import content from other states in states' exports. Consequently, states more specialized in the last stage of the production export more in terms of gross value and so seem more integrated into world markets. Moreover, where inter-state statistics are available to track domestic trade, a good may be counted many times in the production chain in the internal market. However, the export of the good generally happens only once and so is counted only once; usually at the last stage of the production chain in the country. This statistical bias produces extremely high intra national gross trade values for local entities compared to their actual trade with the rest of the world.

\footnotetext{
${ }^{2}$ Wolf (2000) believes these non-linearities may be due to "spatial spillovers on the demand or supply side, spatial clustering of (immobile) factors or an uneven spatial distribution of demand, again coupled with high transportation costs".
} 
The purpose of this paper is precisely to explore the contribution of each Brazilian state to Brazilian exports by using an Input-Output matrix available for each Brazilian States and including the inter-states trade. Input-output analysis is crucial to measure the total import content of exports, either across the whole industry or in the entire country or region, because the national accounts are not merely sufficient to find the first order origin of the value-added. Section II describes the methodology founded on the input-output analysis, as a way of measuring trade in value-added terms and tracking interregional linkages from a value-added point of view. Section III explains the specific method used for the Brazilian Inter-State IO Table built by Guilhoto and Filho (2005) (2010), which is the basic source of data for this paper's analysis and estimations. Section IV provides a descriptive preliminary analysis of the results on the structure of inter-state vertical specialization for export products. Lastly, we present a conclusion on our results.

\section{Methodology: Trade in value-added and interregional input-output tables}

Under the forces of vertical specialization, a better statistical tool focused on the "origin" and "final destination" of the good is required to analyze bilateral trade relations at national level as they are at international level. Measuring trade using the "value-added" approach enables us to approximate the true origin of exports. This may also be used to determine the valueadded contribution at each stage and hence track the value chain through to the end of the production process (Koopman, Powers, Wang, \& Wei, 2010). The bilateral trade flows, estimated on net value, are incidentally corrected for the statistical bias created by the multiple accounting of imported intermediate goods and components embodied in exports.

Conceptually, the gross value of each exported good includes the exporter's value-added and the value-added of the imported inputs incorporated into the good by the foreign and domestic firms at earlier stages of the production chain. Then, for a traded good, the domestic content in exports or the value-added by an exporting entity is measured at first glance as the difference between the gross value of the exported good and the imported inputs used to produce it. ${ }^{3}$ However, part of the imported inputs may be produced by the exporting country at earlier stages. Some primary goods and components might be exported and re-imported after transformation, which complicates the measurement of domestic content in exports. If we use this logic to find the origin of the inputs used and, by extension, the origin of the inputs used to produce these inputs and so on, we can decompose the value of a good $\left(P^{a}\right)$ in the value-added $\left(V_{i}^{a}\right)$ generated across countries or, more broadly, across different geographic entities $(i)$ participating in the production chain.

$P^{a}=\sum_{i} V_{i}^{a}$

Where $P^{a}$ is the gross value of product $a$ and $i$ is the origin of value-added. However, given the complexity of re-exporting and re-importing along the production chains and the

\footnotetext{
${ }^{3}$ In regional input-output works, the flows from one region in a given country to another region of the same country are referred to as interregional trade (or trade) flows and the terms export and import are used only when dealing with foreign trade (Miller \& Blair, 2009). However, we use the terms export, import and trade for flows between all types of geographic entities, countries and sub-regions of a country.
} 
multitude of product production processes, it is tricky to measure the origins of value-added using national accounts.

International input-output tables are commonly used as indirect measure of the import or domestic value content of exports (Hummels, Ishii, \& Yi, The nature and growth of vertical specialization in world trade, 2001), (De Backer \& Yamanao, 2008) and some international organizations are currently supporting the construction of international input-output matrices based on the method introduced by Leontief (1986). More specifically, interregional inputoutput (IRIO) tables can be used to estimate the value-added in traded goods since, unlike standard IO tables, they can track the geographic path of the production chain and the interlinkages among regions.

The input-output tables draw on the flows of products taken from the national accounts to determine the pattern of inter-industry dependencies and their linkages with the final demand elements in an economy for a reference year. Hence, the production technology is assumed to be the same for the period of analysis as for the reference table and the input-output coefficients are assumed to be fixed in the analysis. In the static input-output table, there is a strict dichotomy between quantities and prices, meaning that production has no effect on prices and vice versa. Therefore, there is no substitution across inputs and no gain from economies of scale. Lastly, the supply of labor and capital are unlimited.

Under the above assumptions, input-output tables use the mathematical equality between sales and purchases to analyze the impact of an increase in sales on purchases. To be more precise, the input-output table consists of a closed, endogenous part, which basically concerns the flows of inputs among the industrial sectors of the economy, and the final demand in the economy, which is "exogenous", since it is independent of the industrial production linkages. Further, the analysis can be extended with interdependencies among industrial sectors in different geographic entities, which will then appear in the endogenous part of the interregional input-output (IRIO) table.

On the sales side (IO table row), the output of sector $i\left(x_{i}\right)$ is equal to its supply (sales of inputs) of intermediate goods to other industries $\left(a_{i j} x_{j}\right.$ where $\left.j=1, \ldots n\right)$ for production (output $x_{j}$ ) and to domestic purchasers for consumption, e.g. households (final consumption expenditure), government (government expenditure) and purchasers abroad (exports). The total demand of the consumer agents is called total final demand $\left(f_{i}\right)$.

$x_{i}=\sum_{j=1}^{n} a_{i j} x_{j}+f_{i}$

Where $a_{i j}$ is the technical coefficient calculated as the ratio of inputs from industry $i$ used in the total output of industry $j$. Final demand is exogenous and cannot be predicted by the model.

On the purchase side (IO table column), the output of sector $j\left(x_{j}\right)$ is equal to its purchases of inputs from other industries $i\left(a_{i j} x_{j}\right)$ and its purchases from payment sectors $\left(p_{i}\right)$ e.g. valueadded (labor, remuneration of capital), imports, etc. 
$x_{j}=\sum_{i=1}^{n} a_{i j} x_{j}+p_{i}$

Since each industrial sector $(j)$ needs purchases from payment sectors in addition to inputs from industries $(i)$, technical coefficients $\left(a_{i j}\right)$ have the following features:

$\sum_{i=1}^{n} a_{i j} x_{j}<x_{j} \quad$ and $\quad \sum_{i=1}^{n} a_{i j}<1$

By writing the equation 1 for all industrial sectors $i(i=1, \ldots n)$, we get a system of $\mathrm{n}$ linear equations, which can be represented in matrix form:

$x=A x+f \quad$ and $\quad x=(I-A)^{-1} f=L f$

where

- $\quad x$ is a $\mathrm{n}^{*} 1$ vector of the $\mathrm{n}$ industries' output

- $\quad A$ is an $n^{*}$ n matrix of technical coefficients representing interdependencies between industries

- $f$ is an $\mathrm{n}^{*} 1$ vector of final demand

- $\quad(I-A)^{-1}$ is the Leontief inverse $(L)$

Equation 4 is the touchstone of the input-output analysis since it represents the pattern of inter-industry linkages. It can be used to evaluate the impact of a change in final demand on total output and further measure, based on the equality from the purchase side, its impact on the payment sectors, which includes in part the value-added (using Equation 2).

To be more precise, the volume of gross output required to produce final demand $f=\bar{f}$ is calculated as follows,

$\bar{x}=(I-A)^{-1} \bar{f}=L \bar{f}$

Or equally, we can approximate it as follows ${ }^{4}$ :

$\bar{x}=\bar{f}+A \bar{f}+A^{2} \bar{f}+\cdots$

Then the gross output required to produce $\bar{f}$ will be more than $\bar{f}(\bar{x}>\bar{f})$. This can be explained by round-by-round effects in the input-output analysis. Final demand $\bar{f}$ will be responded to by the productive sectors that the demand initially addresses. These productive sectors will produce $\bar{f}$, with the inputs coming from other sectors $(A \bar{f})$. This first round effect is called the direct effect of the final demand on the economy. However, the sectors producing inputs $(A \bar{f})$ also need inputs, calculated in the second round as $A^{2} \bar{f}$, etc. These secondary,

\footnotetext{
${ }^{4}$ An approximation of $(I-A)^{-1}$ can be made by generalizing the Neumann series. Consider the identity: $(I-A)\left(I+A+A^{2}+\cdots A^{k}\right)=I-A^{k+1}$

which is equal to:$$
\left(I+A+A^{2}+\cdots A^{k}\right)-(I-A)^{-1}=-(I-A)^{-1} A^{k+1}
$$

If $\sum_{\mathrm{i}=1}^{\mathrm{n}} \mathrm{a}_{\mathrm{ij}}<1$ and $\mathrm{a}_{\mathrm{ij}}>0$, then $\lim _{k \rightarrow \infty} A^{k}=0$

Hence,

$(I-A)^{-1}=\left(I+A+A^{2}+\cdots A^{k}\right)$ when $k \rightarrow \infty$
} 
tertiary and so on round effects are called the indirect effect of demand $\bar{f}$ on the economy ${ }^{5}$. The strength of Leontief's inverse $\left((I-A)^{-1}\right)$ is that it captures all these initial, direct and indirect effects in a single measure.

The next step is to calculate the purchases, the value-added contribution (appealed as payment sectors $\left(p_{i}\right)$ in equation 2$)$ of the change in final demand. On this point, we need the vector of value-added coefficients representing the share of value-added in the gross output of each industrial sector to measure the impact of output on value-added.

Let's represent the direct value-added contribution for each industrial sector $(1, \ldots n)$ in the reference IO table with a row vector $v^{\prime} ;{ }^{6}$

$v^{\prime}=\left[\begin{array}{lll}v_{1} v_{2} & \ldots & v_{n}\end{array}\right]$

The value-added coefficients $\left(v_{c}{ }^{\prime}\right)$ are then equal to the initial value-added contribution of each industrial sector divided by that sector's gross output:

$v_{c}{ }^{\prime}=v^{\prime} \hat{x}^{-1}=\left[v_{1} / x_{1} v_{2} / x_{2} \ldots v_{n} / x_{n}\right]$

Where $\hat{x}$ is a diagonal matrix ${ }^{7}$ and $\hat{x}^{-1}=\left[\begin{array}{ccc}1 / x_{1} & \ldots & 0 \\ \vdots & \ddots & \vdots \\ 0 & \ldots & 1 / x_{n}\end{array}\right]$

Then from the matrix algebra and by using the equation 8 for $v_{c}{ }^{\prime}$, we can calculate a column vector $(\varepsilon)$ whose elements measure the value-added (initial, direct and indirect) generated in each sector in order to produce final demand $f$. More precisely, returning to our example with final demand $\bar{f}, \bar{\varepsilon}$ is equal to

$\bar{\varepsilon}=v_{c}^{\prime} \bar{x}=v_{c}{ }^{\prime} L \bar{f}$

Interregional input-output (IRIO) tables introduce another aspect of information into the analysis by extending into interdependencies in space. In IRIO tables, the industrial sectors in a region also need inputs from other regions in order to produce. Then the basic difference between standard IO tables and IRIO tables is that the IO tables consider sales to other regions as exports and account for them in the final demand, while IRIO tables see the production of the regions as interdependent and therefore endogenous. In IRIO models, exports, as an element of total final demand, refer to goods sold to the regions outside the model's geographic scope and hence to the purchasers exogenous to the production sectors. However, as an element of final demand, we have equally the sales for the final consumption in each region.

\footnotetext{
${ }^{5}$ The definitions of initial, direct and indirect effects can be found in Foundations of IO Analysis by Miller and Blair (2009). However, in the literature, it is also common to refer to the initial effect as part of the direct effects.

${ }^{6}$ Please see Miller and Blair (2009, pp. 243-271), for further details.

7 The "hat" over vector $x$ denotes the diagonal matrix whose elements are situated along the diagonal. Since $(\hat{x})(\hat{x})^{-1}=I$

Then $\hat{x}=\left[\begin{array}{ccc}x_{1} & \ldots & 0 \\ \vdots & \ddots & \vdots \\ 0 & \ldots & x_{n}\end{array}\right]$
} 
Let's take, for example, an IRIO table for two regions ( $r$ and $s$ ), with each having two industrial sectors $(i$ and $j$ ). In this case, the Leontief inverse is calculated by a two-region input-output table. The output of industry $i$ in region $r$ is equal to:

$x_{i}^{r}=a_{i i}^{r r} x_{i}^{r}+a_{i j}^{r r} x_{j}^{r}+a_{i i}^{r s} x_{i}^{s}+a_{i j}^{r s} x_{j}^{s}+f_{i}^{r}$

Equation 10 can be generalized in matrix form,

$x=(I-A)^{-1} f=L f$

Where $A$ is the interregional input-output coefficient matrix:

$A=\left[\begin{array}{llll}a_{i i}^{r r} & a_{i j}^{r r} & a_{i i}^{r s} & a_{i j}^{r s} \\ a_{j i}^{r r} & a_{j j}^{r r} & a_{j i}^{r s} & a_{j j}^{r s} \\ a_{i i}^{s r} & a_{i j}^{s r} & a_{i i}^{s S} & a_{i j}^{s S} \\ a_{j i}^{s r} & a_{j j}^{s r} & a_{j i}^{s S} & a_{j j}^{s S}\end{array}\right]$

and the output vector $x$ is equal to:

$$
x=\left[\begin{array}{l}
x_{i}^{r} \\
x_{j}^{r} \\
x_{i}^{S} \\
x_{j}^{s}
\end{array}\right]
$$

Therefore, the output required to produce the final demand in one region can be decomposed by region of origin and industry. The impact of an increase in the output of one region over the output of other regions is called a "spillover effect" in the literature. To be more precise, in our example, the output required from sector $i$ in region $r\left(\bar{x}_{i}^{r}\right)$ to respond to the final demand in region $s$ from sector $j\left(\bar{f}_{j}^{S}\right)$ is equal to:

$\bar{x}_{i}^{r}=l_{i j}^{r s} \bar{f}_{j}^{s}$

$l_{i j}^{r s}$ is the element of the interregional Leontief inverse matrix $(L)$ concerning trade from sector $i$ in region $r$ to sector $j$ in region $s$.

$$
L=(I-A)^{-1}=\left[\begin{array}{llll}
l_{i i}^{r r} & l_{i j}^{r r} & l_{i i}^{r s} & l_{i j}^{r s} \\
l_{j i}^{r r} & l_{j j}^{r r} & l_{j i}^{r s} & l_{j j}^{r s} \\
l_{i i}^{s r} & l_{i j}^{s r} & l_{i i}^{s S} & l_{i j}^{s S} \\
l_{j i}^{s r} & l_{j j}^{s r} & l_{j i}^{s S} & l_{j j}^{s S}
\end{array}\right]
$$

Then, the value-added coefficient $\left(v_{c}\right)_{i}^{r}$ for industry $i$ in region $r$ is calculated as the ratio of the industry's direct value-added to its total output from the reference IRIO table. The valueadded contribution $\left(\bar{\varepsilon}_{i}^{r}\right)$ of sector $i$ in region $r$ due to spillover impact of the final demand from industrial sector $j$ in region $s\left(\bar{f}_{j}^{s}\right)$ is:

$\bar{\varepsilon}_{i}^{r}=\left(v_{c}\right)_{i}^{r} * l_{i j}^{r s} \bar{f}_{j}^{s}$ 
The general matrix computation is similar to equation 9; value-added contribution $(\bar{\varepsilon})$ of each industry-region pair for the final demand $(\bar{f})$ can be calculated by following matrix computation:

$\bar{\varepsilon}=v_{c}^{\prime} \bar{x}=v_{c}^{\prime} L \bar{f}$

At international level, a form of IRIO table, an international input-output table has been constructed by the World Input-Output Tables project funded by the European Commission of Research $^{8}$. The OECD also has national IO tables for some countries showing the import volume for each export sector (OECD, 2011). However, the distinction between imported input allocated to domestic final demand and to exports is not always obvious. For example, for China, the estimated share of import content is significantly higher when input imports by EPZs are distinguished from ordinary production for exports (Pei, Dietzenbacher, \& Oosterhaven, 2010). For Brazil, this restriction has few consequences because the country has no EPZs, the Manaus Free Trade Zone having to be considered as an "import" processing zone where production is mainly dedicated to the domestic market.

In our work, we will concentrate on the interregional input-output table for Brazilian states, which traces the geographic fragmentation of production across the states and hence shows the "origin" state of Brazilian foreign exports.

\section{The construction of the Brazilian Inter-state input-output table}

The Brazilian inter-state input-output system for 27 regions (26 states and the Federal District) for 2008 was estimated based on a combination of different sources of data and methodologies. We first detail the data available to estimate the Brazilian input-output table and then address the construction of the inter-state input-output system.

The most recent input-output system released by the Brazilian Statistical Office (IBGE) refers to 2005 (IBGE, 2008). However, using the information available in the Brazilian System of National Accounts (IBGE, 2010) and the methodology presented by Guilhoto and Filho (2005) (2010), we can estimate an input-output system for Brazil for the most recent years based closely on the Brazilian input-output systems released by the IBGE. From the above, a national input-output system was estimated for 2008, consisting of national supply and use tables, giving basic prices, at the level of 56 industries and 110 commodities. The estimated national input-output system was then used as the basis to estimate the inter-state system for Brazil based on the methodology presented in Guilhoto et al. (2010).

The steps followed for the estimation of the inter-state system for Brazil can be summarized as follow ${ }^{9}$ :

\footnotetext{
${ }^{8}$ Data are available on www.wiod.org.

${ }^{9}$ See Figure 1 in Appendix 1, which summarizes the work needed to estimate the inter-state input-output system for Brazil.
} 
- Using information from the IBGE surveys of Agriculture, Industry, Trade, Transport, Services, and Civil Construction, a first estimate is made of total output by 56 industries and 110 commodities for each of the Brazilian states;

- These initial estimates are then balanced to match the total output at the level of 17 industries presented in the Brazilian Regional Accounts (IBGE);

- These output estimates are also used to estimate the supply tables for each of the Brazilian states. The states' supply tables are estimated in such a way as to be consistent with the national supply table;

- Using information: a) on imports by state, from the Ministry of Development, Industry and External Trade; b) on tax collection in each state, from the Ministry of Finance and the State Secretaries of Finance; c) on payments to workers by industry and state, from the Ministry of Labor and the IBGE Household Survey; d) on value-added generated at the level of 17 industries, by state, presented in the Brazilian Regional Accounts (IBGE), the tax, imports, and value-added components are estimated for the 56 industries for each of the Brazilian states, which are also consistent with the valueadded components in the national input-output table;

- Using information: a) on exports by each state, from the Ministry of Development, Industry and External Trade; b) on government spending estimated by the Ministry of Finance, the States Secretaries of Finance and the IBGE; c) on household spending estimated by the Household and Household Consumption Patterns surveys; d) on investment based on the level of the Civil Construction in each state (IBGE), the input-output system's final demand components are estimated for each state, which are consistent with the national input-output table;

- Using cross-industry location quotients for intermediate consumption and simple location quotients for final demand, a first estimation is made of flows of goods and services among the Brazilian states;

- Using the work done by Vasconcelos and Oliveira (2006), which estimates the flow of goods among Brazilian states for 1999, and taking into consideration the growth of the states from 1999 to 2008, a second estimation is made of flows of goods and services among the Brazilian states;

- The third and final estimation of flows of goods and services among the Brazilian states is made taking into consideration the following: a) the inter-state input-output system should be consistent with the national table; b) the change in inventories should be zero when they are zero in the national table; c) the change in inventories in each state, when related to the total output of the corresponding sector should be in a range no greater than $30 \%$ of this relation found in the national table;

- The third estimation produces a commodity by industry inter-state input-output system for Brazil. The supply tables for each of the states are then used to obtain the industryby-industry inter-state system used in this work. 


\section{Vertical specialization in Brazil}

The diversified nature of Brazilian states' characteristics, such as factor endowments, economic sizes, infrastructures, etc., may drive vertical specialization at national level. Foreign demand will also drive state specialization in tasks in order to take advantage of economies of scale. The exported goods are then produced by a sequence of tasks in which one or more Brazilian states are involved. Hence, the value of gross exports from one state may partly include the value-added from other states, which inter-link the foreign trade with inter-state trade.

On this purpose, we calculate the value-added contribution of each state for states' exports. They are computed by inversing the technical coefficient matrix from Inter-state Input-Output system for the year 2008. In our input-output system, the gross exports of each state $(s)$ is driven by the demand exogenous to the inter-state production chain, hence is an element of final demand $(f)$ addressed to state $s$. In order to respond the final demand addressed $(\bar{f})$, state $s$ will produce the output $\bar{x}^{s}\left(\bar{x}^{s}=L^{s} \bar{f}\right)$ and the state $r$ will participate to production process and produce $\bar{x}^{r}\left(\bar{x}^{r}=L^{r} \bar{f}\right)$ due to spill-over impacts. Then, we appeal the value-added contribution $\left(v_{c}^{S} * \bar{x}^{s}\right)$ of state $s$ as "direct value-added contribution" of $s$ to its exports and the spill-over impact as "indirect value added contribution" of state $r$ to the exports of $s$ $\left(v_{c}^{r} * \bar{x}^{r}\right)$.

\section{Graph 1: Breakdown of Brazilian states' gross exports (2008)}

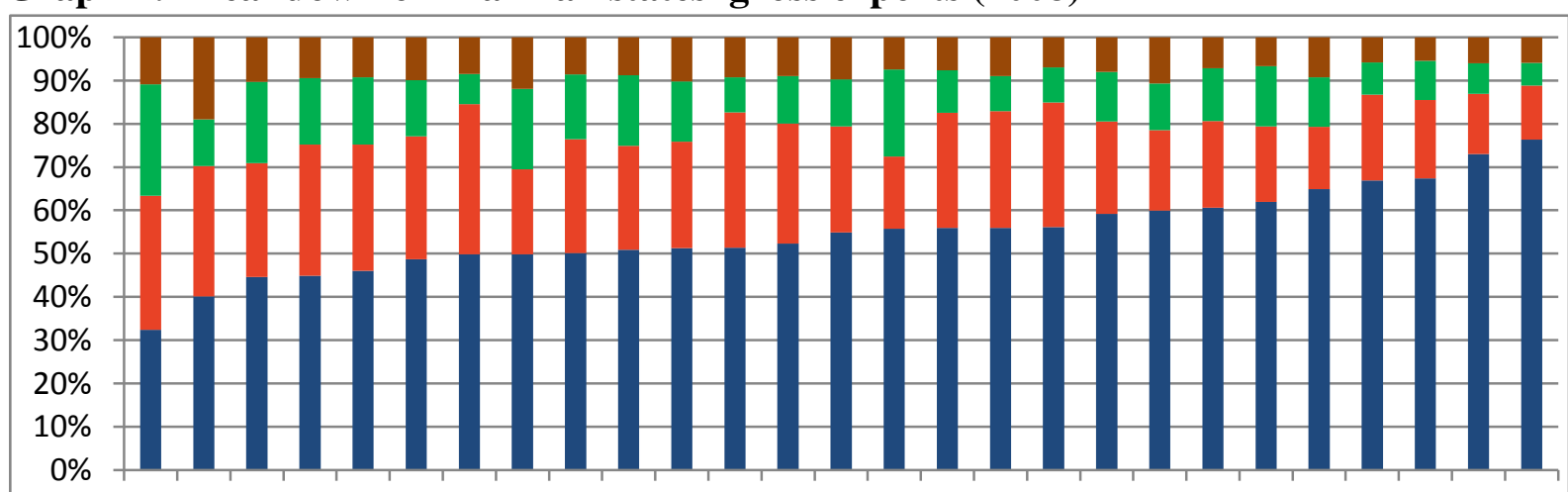

AM DF MS PR BA GO AL SP SC RS PE SE PB CE MAMT RN ROMG ES PA AP RJ PI TO RR AC

- Tax Imports from World $\quad$ Other Brazilian States $\quad$ Added value of state itself

Source: 2008 Inter-State Input-Output Table calculated in association with J. Guilhoto (USP) based on the NEREUS database. Some elements are available on http://guilhotojjmg.wordpress.com/banco-de-dados/matrizes-nacionais-2/ See Appendix 2 for the states' two-letter codes.

In Graph 1, we show the percentage share of the gross export values of each state broken down by the value-added of the state itself (direct value-added contribution), the value-added originating in other states and re-exported (indirect value-added contribution), the gross imports from other countries ${ }^{10}$ and the tax collected by Brazil, at different administrative levels, by federal and state governments or by municipalities. To be more precise, for the

\footnotetext{
${ }^{10}$ Notice that the importation of the state is not decomposed by its origin hence, it can include in part the value added originated from itself or other Brazilian states and re-imported as embodied in its imports from world (e.g. SP-France-SP or SP-France-AM).
} 
example of São Paulo (SP), the value-added produced by the state itself represents approximately $50 \%$ of SP's gross exports, while the value-added of 26 other states embodied in SP's gross exports is $20 \%$. The content imported from the world is also approximately $20 \%$.

In average, $54 \%$ of states' exports are produced by themselves while $24 \%$ is the domestic import content re-exported. The foreign import content in states' exports is around $12 \%$ on average, which is in line with the OECD-WTO "Trade in Value Added" data $(10,9 \%$ in 2008). However, percentages vary across states. Three small states (Roraima (RR), Acre (AC) and Tocantins (TO)) in the Northern region, which are relatively isolated from the rest of the country, have more than $70 \%$ of their own value-added in their exports. The states of Minas Gerais (MG), Pará (PA), Amapá (AP), Espírito Santo (ES), Piauí (PI) and Rio de Janeiro (RJ) also post a higher than average (more than 54\%) domestic value-added share in their gross exports. This result may be explained by the states' large exports of natural resources, such as minerals for MG and iron ore for PA, which is the leading iron mining area in the country (Neto, 2001). In the case of the state of Amazonas (AM), where the Manaus Free Trade Zone (MFTZ) is situated, the domestic value-added share is the lowest of all the Brazilian states at $32 \%$. However, the value-added originating from other states (domestic import content) is around $31 \%$, which is higher than the foreign import content (26\%). In comparison with other free trade zones (like Chinese "export processing zones") this low share of import content is surprising, even though it is much higher than the Brazilian states' average foreign import content (12\%). However, the comparison is not relevant because the Free Trade Zone of Manaus is dedicated to domestic market and direct exports represent a negligible share of the production.

In Graph 2, we trace the picture from the point of the origin state $r$-instead of the exporter state $s$ - of value-added and present the total value-added exported directly by the state itself and by other states indirectly, which means re-exported embodied in the exports of other states. On average, $54 \%$ of states' exported value-added is realized directly by themselves while $46 \%$ is exported indirectly, via other states. Graph 2 shows that states are very different from each other in terms of the share of their direct-indirect exported value-added shares. This result highlights, as does Graph 1, that state inclusion in the national production chain of Brazilian exports is highly diverse and virtually non-existent in some states, e.g. Pará (PA) (approximately $90 \%$ of exported value-added is direct). Other states with high mineral resources also export their output relatively directly (Minas Gerais (MG) and Pará (PA)). Also the rich and industrial states of the South and South-East, with their advantageous access to international markets, appear to export their own value-added by themselves (Espírito Santo (ES), Rio Grande do Sul (RS), São Paulo (SP), Rio de Janeiro (RJ) and Santa Catarina (SC)). These features are relatively more complicated to interpret for poor states, e.g. while Sergipe (SE) exports very little of its value-added itself, Tocantins (TO) posts the Brazilian average. If Amazonas (AM) exports few directly, as said previously, its value-added is in large part indirectly exported, which can be explained by the MFTZ special tax scheme to integrate the zone into the Brazilian domestic market.

\section{Graph 3: Indirectly and directly exported value-added of states (\%)}




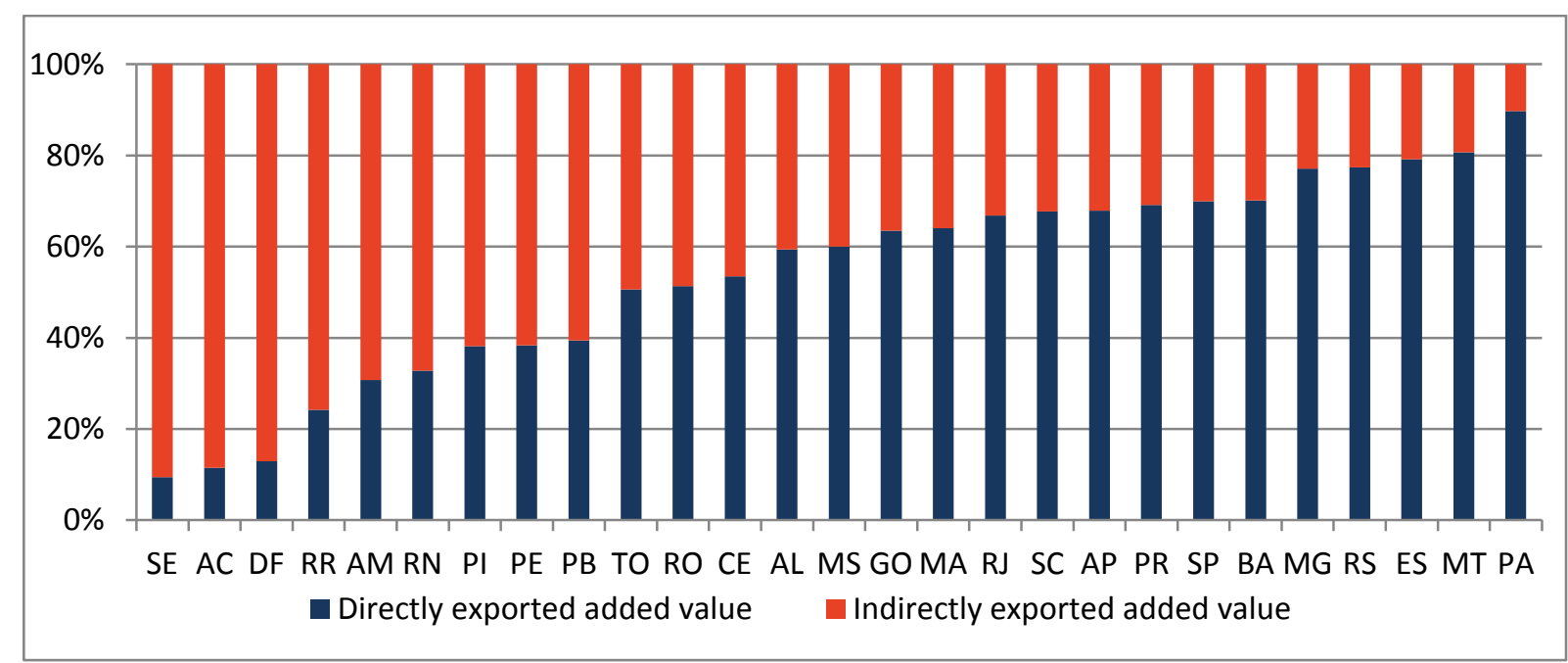

Source: 2008 Inter-State Input Output Table calculated by J. Guilhoto at USP.

The above two graphs present the structure of vertical specialization in the Brazilian internal market for export products. Aside from states that directly export primary products, industrial production in large states is dependent on other states. States' exports (São Paulo (SP), Santa Catarina (SC), Rio Grande do Sul (RS), and Amazonas (AM) in Graph 1) create a demand for other states. Graph 2 shows the states that serve as suppliers (Amazonas (AM), Rio Grande do Norte (RN), Piauí (PI), Pernambuco (PE), etc.).

\section{Graph 3: States' gross exports and value-added share in Brazilian total (\%)}

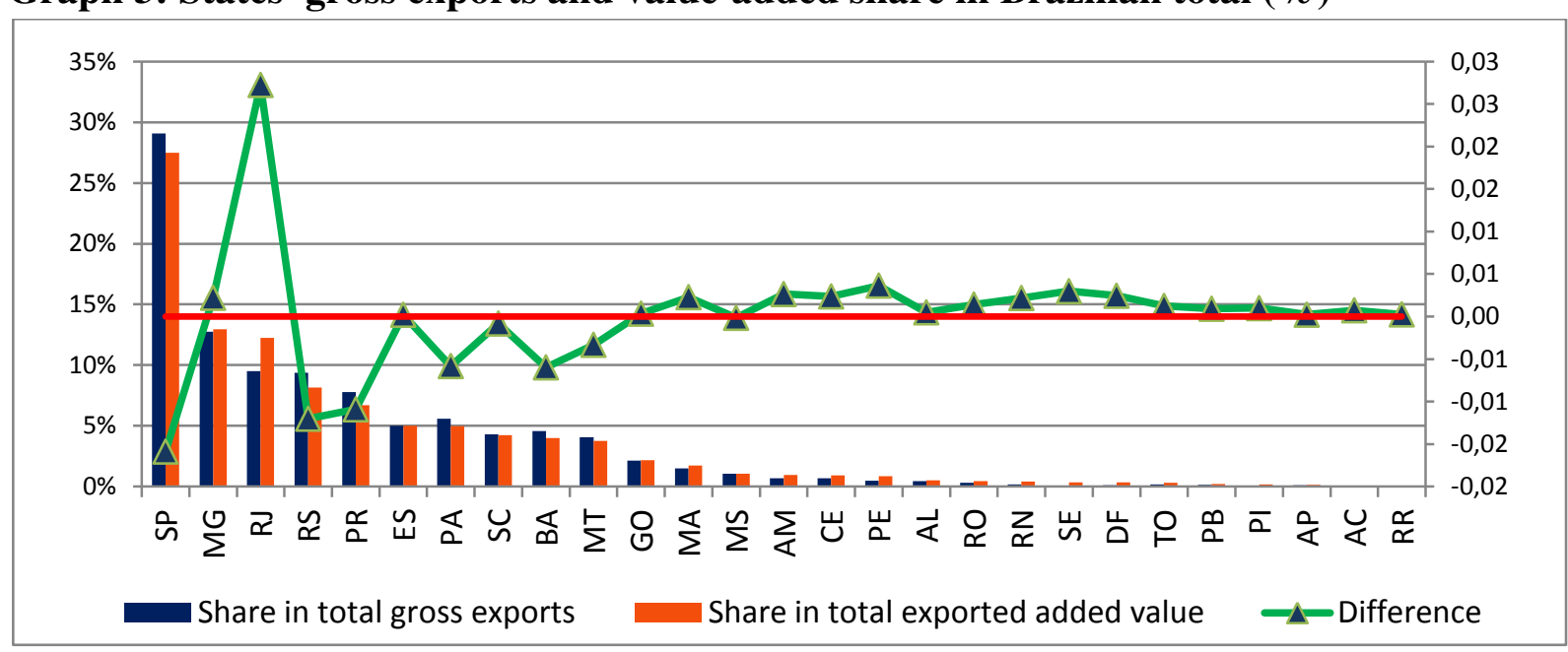

Source: 2008 Inter-State Input Output Table calculated by J. Guilhoto at USP.

However, another interesting issue is the comparison between the structures of states' gross exports and the structure of their exports in value-added terms. Hence, in Graph 3 we present the share of states' exports in Brazilian total gross exports and their value-added share exported directly or indirectly - in Brazilian total exported value-added.

Graph 3 shows that the states' exports shares (\%) in value-added terms and in gross terms are very similar, with the difference between two indicators generally being zero or close to zero. Rio de Janeiro (RJ)'s share in exported value-added seems to be relatively larger than it is in gross terms. São Paulo (SP), however, has a higher percentage of its exports in Brazilian total 
gross exports. However, these differences are very marginal: $3 \%$ for Rio de Janeiro (RJ) and $1.6 \%$ for São Paulo (SP).

\section{Conclusion:}

Our work discusses the implications of "vertical specialization" by extending the subject to an intra-national trade analysis for Brazilian states. We use the Brazilian Inter-State Input-Output table for 2008, to calculate states' value-added exported directly on its own and indirectly via other states. If the level of vertical specialization is relatively low concerning international trade, we show evidence that inter-states trade is quite high for some Brazilian states. Vertical specialization then operates at upstream stages of the value chain. The analysis shows that, with the exception of states that export natural resources, Brazilian states' exports are inter-linked by internal production chains, driven by the demand of rich southern and south-eastern states (São Paulo (SP), Santa Catarina (SC), etc. ) and supplied by relatively poorer states (Rondônia (RO), Piauí (PI), etc.). However, our results also find considerable directly exported valueadded for some poor states. The analysis further highlights the special status of the state of Amazonas (AM) in Brazilian inter-state vertical specialization. Amazonas (AM) is both a supplier for other states' exports and a consumer of intermediate goods from other states, which are then re-exported to the rest of the world.

\section{References}

Ali-Yrkkö, J., Rouvinen, P., Seppälä, T., \& Ylä-Anttila, P. (2011). Who Captures Value in Global Supply Chains? Case Nokia N95 Smartphone. Journal of Industry, Competition and Trade, 11(3), pp. 263-278.

De Backer, K., \& Yamanao, N. (2008). The Measurement of Globalisation using International InputOutput. STI workin paper 2007/8, OECD.

Dedrick, J., Kraemer, K. L., \& Linden, G. (2010). Who Profits from Innovation in Global Value Chains? A Study of the iPod and notebook PCs. Industrial and Corporate Change, 19(1), pp. 81-116.

Escaith, H., Lindenberg, N., \& Miroudot, S. (2010). International Supply Chains and Trade Elasticity in Times of Global Crisis". WTO,Staff Working Paper ERSD-2010-08, February.

Grossman, G. M., \& Rossi-Hansberg, E. (2006). The Rise of Offshoring: It's Not Wine for Cloth Anymore. Federal Reserve Bank of Kansas City: Proceedings, 59-102.

Guilhoto, J. J., \& Filho, U. A. (2005). Estimação da Matriz Insumo-Produto a Partir de Dados Preliminares das Contas Nacionais. Economia Aplicada, 9(2), pp. 277-299.

Guilhoto, J. J., \& Filho, U. A. (2010). Estimação da Matriz Insumo-Produto Utilizando Dados Preliminares das Contas Nacionais: Aplicação e Análise de Indicadores Econômicos para o Brasil em 2005. Economia \& Tecnologia. UFPR/TECPAR, 6(23), pp. 53-62.

Guilhoto, J. J., Azzoni, C. R., Ichihara, S. M., Kadota, D. K., \& Haddad, E. A. (2010). Matriz de InsumoProduto do Nordeste e Estados: Metodologia e Resultados (Input-Output Matrix of the 
Brazilian Northeast Region: Methodology and Results). Fortaleza: Banco do Nordeste do Brasil.

Hummels, D., Ishii, J., \& Yi, K.-M. (2001). The nature and growth of vertical specialization in world trade. 54(1), pp. 75-96.

Hummels, D., Rapoport, D., \& Yi, K.-M. (1998). Vertical specialization and the changing nature of world trade. Federal Reserve Bank of New York: Economic Policy Review(June), pp. 79-99.

IBGE. (2008). Matriz de Insumo-Produto Brasil: 2000-2005. Rio de Janeiro: Instituto Brasileiro de Geografia e Estatística-IBGE .

IBGE. (2010). Sistema de Contas Nacionais Brasil: 2004-2008. Rio de Janeiro: Instituto Brasileiro de Geografia e Estatística - IBGE.

Johnson , R. C., \& Noguera , G. (2012). Fragmentation and Trade in Value Added over Four Decades,. NBER Working Paper No. 18186.

Koopman , R., Wang , Z., \& Wei , S.-J. (2012). Tracing Value-Added and Double Counting in Gross Exports. NBER Working Paper Nº18579.

Koopman, R., Powers, W., Wang, Z., \& Wei, S.-J. (2010). Give Credit Where Credit Is Due: Tracing Value Added in Global Production Chains. NBER Working Paper N 16426, September.

Koopman, R., Wang, Z., \& Shang-Jin, W. (2008). How Much of Chinese Exports is Really Made In China? Assessing Domestic Value-Added When Processing Trade is Pervasive. NBER Working Paper No. 14109, June.

Leontief, W. (1986). Input-Output Economics (2nd ed.). New York: Oxford University Press.

Liu, B. (2011). Why World Exports are so Susceptible to the Economic Crisis --The Prevailing "Export Overshooting Phenomenon. NBER Working Paper No. 16837, February.

Maurer , A., \& Degain, C. (2010). Globalization and trade flows: what you see is not what you get! Geneva: WTO ERSD-2010-12 ; June.

Miller, R. E., \& Blair, P. D. (2009). Input-Output Analysis: Foundations and Extensions. (2nd ed.). Cambridge University Press.

Neto, A. L. (2001). Lessons from Brazil's regional development policies. Conference on Foreign Investment in China's Regional Development, October.

OECD. (2011). Import content of exports 2011. Paris: OECD Science, Technology and Industry Scoreboard.

OECD-WTO. (2012). Trade in value-added: concepts, methodologies and challenges (Joint OECD-WTO Note). Retrieved from http://www.oecd.org/sti/industryandglobalisation/49894138.pdf.

Pei, J., Dietzenbacher, E., \& Oosterhaven, J. (2010). The bias in accounting for national income changes when pervasive processing trade is present, Draft Paper, April. Retrieved from 
http://www.iioa.org/files/conference-

1/39_20100426031_Thebiasinaccountingfornationalincomechanges.pdf.

Vasconcelos, J. R., \& Oliveira, M. A. (2006). Análise da matriz de fluxo do comércio interestadual no Brasil. Rio de Janeiro: IPEA.

Wolf, H. C. (2000). Intranational Home Bias In Trade. The Review of Economics and Statistics, 82(4), pp. 555-563.

World Economic Forum. (2012). The Shifting Geography of Global Value Chains: Implications for Developing Countries and Trade Policy. World Economic Forum.

WTO, \& IDE-JETRO. (2011). Trade Patterns and global value chains in East Asia: From trade in goods to trade in tasks. Geneva; WTO. 


\section{APPENDIX}

\section{Appendix I}

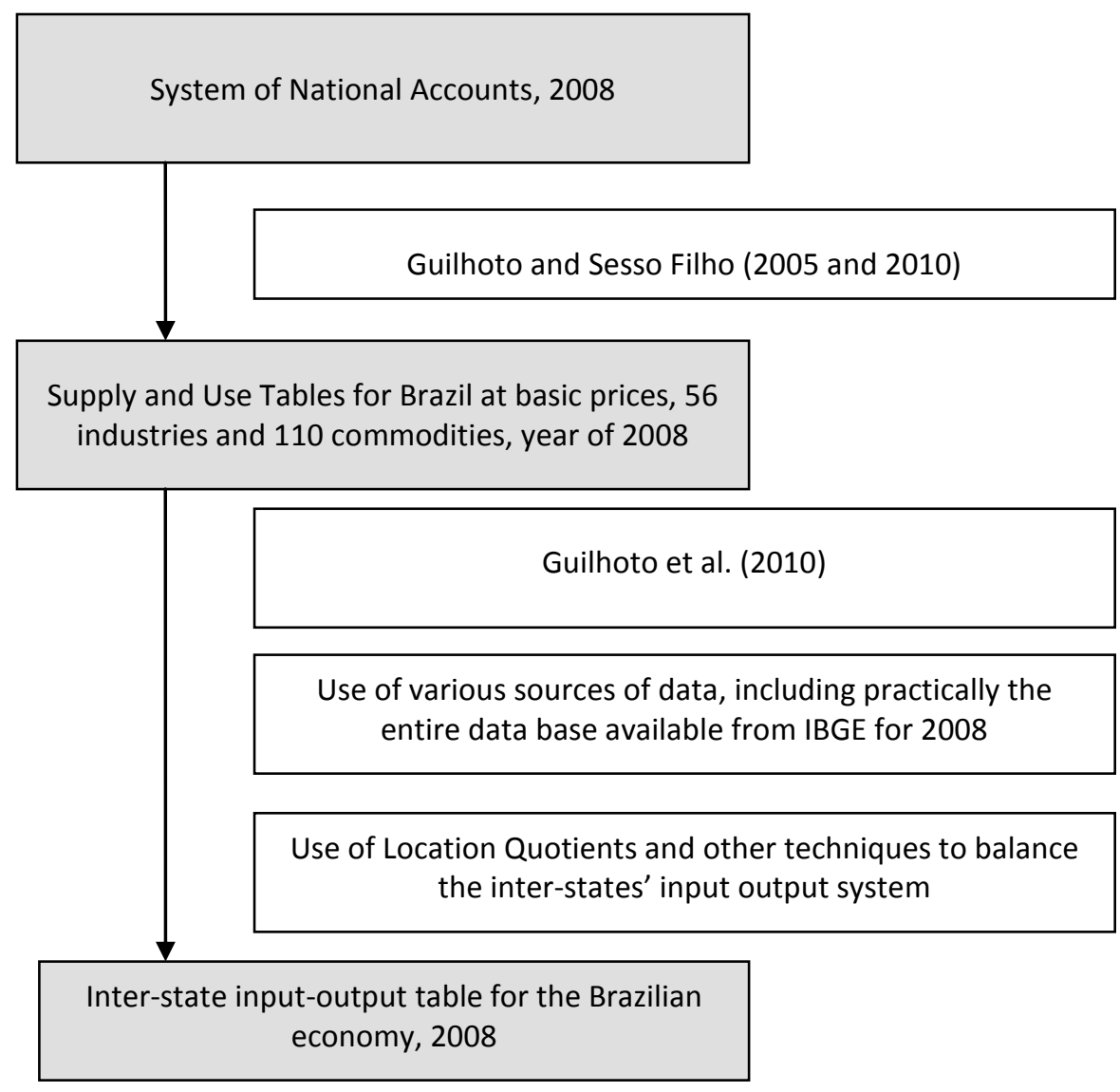

Figure 1

Estimating the Inter-State Input-Output System for Brazil for 2008 


\section{List of Brazilian states and their abbreviations:}

\begin{tabular}{|l|l|}
\hline ACRE & AC \\
\hline ALAGOAS & AL \\
\hline AMAZONAS & AM \\
\hline AMAPA & AP \\
\hline BAHIA & BA \\
\hline CEARA & CE \\
\hline DISTRITO FEDERAL & DF \\
\hline ESPIRITO SANTO & ES \\
\hline GOIAS & GO \\
\hline MARANHAO & MA \\
\hline MINAS GERAIS & MG \\
\hline MATO GROSSO DO SUL & MS \\
\hline MATO GROSSO & MT \\
\hline PARA & PA \\
\hline PARAIBA & PB \\
\hline PERNAMBUCO & PE \\
\hline PIAUI & PI \\
\hline PARANA & PR \\
\hline RIO DE JANEIRO & RJ \\
\hline RIO GRANDE DO NORTE & RN \\
\hline RONDONIA & RO \\
\hline RORAIMA & RR \\
\hline RIO GRANDE DO SUL & RS \\
\hline SANTA CATARINA & SC \\
\hline SERGIPE & SE \\
\hline SAO PAULO & SP \\
\hline TOCANTINS & TO \\
\hline & \\
\hline
\end{tabular}

